\title{
Changes and Developments in the BRICS Agenda for Future Presidencies ${ }^{1}$
}

\author{
Sh. Guo, H. Zhang, W. Shi
}

Shuyong Guo - Professor, Dean of the School of International Relations and Public Affairs (SIRPA) at Shanghai International Studies University (SISU); 550 Dalian Road (W), Shanghai 200083, China; E-mail: syguo@shisu.edu.cn

Hanwen Zhang - PhD Candidate at the School of International Relations and Public Affairs (SIRPA) at Shanghai International Studies University (SISU); 550 Dalian Road (W), Shanghai 200083, China; E-mail: 0174100989@shisu.edu.cn

Weiping Shi - PhD Candidate at the School of International Relations and Public Affairs (SIRPA) at Shanghai International Studies University (SISU), Associate Professor at Shanghai University of Traditional Chinese Medicine; 550 Dalian Road (W), Shanghai 200083, China; E-mail: susanswp@126.com

\begin{abstract}
In 2009, the first summit of the leaders of what would become known as the BRICS countries (Brazil, Russia, India, China and later, South Africa) was held in the Russian city of Yekaterinburg. Since then, "BRICS" has gradually evolved from an academic concept to a cooperation mechanism that has played an ever-greater role in the international political arena. In the past 10 years, the agendas of BRICS summits have been enriched and its action plans have been pragmatic and effective. This article analyzes the agendas of the 10 summits to date and explores the factors that shaped them. Finally, the article analyzes trends for future agendas and explores the complex difficulties and challenges faced by the BRICS countries in the international environment. It concludes with suggestions about how to resolve these difficulties and challenges through future cooperation.
\end{abstract}

Key words: BRICS; summit agenda; global governance; emerging powers

For citation: Guo Sh., Zhang H., Shi W. (2019) Changes and Developments in the BRICS Agenda for Future Presidencies. International Organisations Research Journal, vol. 14, no 2, pp. 109-127 (in Russian and English). DOI: 10.17323/1996-7845-2019-02-05.

\section{Introduction}

The BRICS group of countries is made up of Brazil, Russia, India, China and South Africa, five countries located on four continents in two hemispheres. The sum of their land mass accounts for $29.6 \%$ of the world's territory and the proportion of their collective population to that of the world is $42.6 \%$ [National Bureau of Statistics of China, 2017]. References to "BRIC" date back to 2001. In a report entitled "Building Better Global Economic BRICs," Jim O'Neill, the former chief economist for Goldman Sachs, referred to Brazil, Russia, India and China as "BRIC countries," and claimed that they are the fastest growing emerging economies in the world

${ }^{1}$ The editorial board received the article in October 2018.

This article was supported by the Shanghai International Studies Uneversity, instructor-led program "Civilization Dialogue and Social Construction: Based on the Perspective of International Political Sociology." 
[O’Neill, 2001]. In 2003, Goldman Sachs published a research report entitled "Dreaming With BRICs: The Path to 2050" which predicted that BRIC countries will among the top six in the world economy along with the United States and Japan by 2050 in terms of purchasing power parity [Wilson, Purushothaman, 2003]. Later, various companies and institutions successively published relevant reports and research which further made this concept popular. BRICs was originally a business investment concept hyped by investment banks and international financial markets. However, with their increasingly close economic and trade ties and the gradual construction of a collective identity, the cooperation foundation between BRICs deepened and they began to engage in non-institutionalized political activities. At the initiative of Russia, the four countries held their first foreign ministers meeting during the United Nations (UN) General Assembly in September 2006, and in June 2009 the first summit meeting was held in the Russian city of Yekaterinburg. In November 2010, South Africa officially requested membership in the BRICs cooperation mechanism during the G20 meeting in Seoul, transforming the BRIC group into BRICS. So far, the BRICS countries have held 10 leaders summits, reached important consensus on many issues and achieved significant results.

\section{Four Factors Affecting the BRICS Agenda}

\section{Internal Factor: A Common Identity as Emerging Powers}

A very important reason for bringing the BRICS countries together is that they are all emerging powers - they are developing countries that have achieved high levels of development and are likely to become world economic powers in the future, with relatively strong economic growth rates and advantages of population, land and comprehensive strength [Zhu, 2010].

Starting from common characteristics, BRICS countries gradually formed a cooperation mechanism to manage the common interests and joint actions that can be attributed to their complementarity and similarity. The potential for greater economic cooperation among the five countries can be envisioned because of their respective strengths in terms of resource endowment and industrial structure. BRICS represents the largest group of intercontinental emerging middle-income powerhouse economies [Budhwar et al., 2017]. BRICS states have the world's largest populations, especially India and China, and have experienced rapid growth over the last two-to-three decades, only recently experiencing a slight slowdown [Horwitz, Budhwar, 2015 , p. 4]. Russia is called "the world's gas station" due to its considerable oil and natural gas resources. It boasts advantages of basic science and thriving aerospace and military industries. India is called "the world's office," taking the lead in computer and software industries even though its industrial manufactured goods are relatively weak. Brazil's modern agriculture and clean technology are more dominant and it is known as the "world's raw material base" because of its rich mineral resources. South Africa is recognized as the gateway to Africa and the bridgehead for African development, boasting enormous resources and advanced mining technology [Li, 2013]. BRICS countries are closely linked by a common identity and shared interests. On the one hand, BRICS countries are different from the developed economies represented by the Group of 7 (G7), while on the other hand they differ from ordinary developing countries in terms of their national scale, development speed and potential, and international ambition. As emerging market countries and Group of 20 (G20) members, they have a shared interest in optimizing the industrial structure, reforming the governance structure of the international economy, promoting their international status and participating in global governance [ $\mathrm{Li}, \mathrm{Xu}$, 2015]. Faced with the economic structure dominated by the western countries and impacted by the global financial crisis, the BRICS countries are more deeply aware of the consequences of the crisis and feel the great pressure of trade protectionism. Therefore, they have to speak with 
one voice and take joint actions to strive for a favourable international environment for their own transformation and development.

In retrospect, it is the overarching desire for peace, security, development and cooperation that brought the BRICS countries together 10 years ago. Upholding development and multilateralism, they are working together for a more just, equitable, fair, democratic and representative international political and economic order. Guided by shared goals and aspirations, the agenda of the BRICS summit should take international and regional issues of common concern as the starting point. The agenda aims to maintain equality and solidarity, keep openness and inclusiveness, build an open world economy and deepen cooperation with emerging markets and developing countries. The agenda directs the five countries to work together for mutually beneficial outcomes and common development, and to constantly deepen the practical cooperation among them which benefits the world at large. Under the influence of such internal factors, various agendas and action plans have been formulated that meet the development needs of BRICS countries.

\section{External Factor: The Current International Political Situation and Economic Development}

The BRICS agenda is rooted in the status quo of the common development of the BRICS countries and is also influenced by the international situation. Cooperation within BRICS must be viewed in the historical context of global development and the evolution of the international structure. We are in an era of development, transformation and adjustment. The world today is becoming increasingly multipolar; the economy has become globalized, there is growing cultural diversity and society has become digitized. The "law of the jungle" according to which the strong prey on the weak, and zero-sum games in which one's gain is another's loss, are rejected. Peace, development and win-win cooperation have become the shared aspiration of all peoples. Against this backdrop, many emerging markets and developing countries have come to the fore, playing an ever-greater role in international affairs.

The sudden outbreak of the 2008 global financial crisis left the world economy reeling, and it has yet to fully recover. Facing this external shock, the BRICS countries have leveraged their respective strengths and converging interests and have put in place a leader-driven cooperation framework that covers wide-ranging areas and multiple levels. A number of cooperation projects have been launched. In particular, the New Development Bank (NDB) and the Contingent Reserve Arrangement (CRA) have provided financing support for infrastructure and sustainable development in BRICS countries, contributing to enhanced global economic governance and the building of an international financial safety net. In the past 10 years, BRICS' combined gross domestic product (GDP) has grown by $179 \%$, trade by $94 \%$ and urban population by $28 \%$. All of this has contributed significantly to stabilizing the global economy and returning it to growth, and it has delivered tangible benefits to over 3 billion people [National Bureau of Statistics of China, 2017]. BRICS has promoted reform of global economic governance to increase the representation and voice of emerging market and developing countries. The inclusive improvement of the international institutions and systems by the BRICS countries has significant implications for the construction of a new international relations system and world order [Guo, Shi, 2015]. The BRICS countries endeavour to fulfil their international responsibility in the face of complex and ever-changing international political situations including constant regional conflicts, the increasingly prominent nontraditional security crisis and the threat of international terrorism. Committed to multilateralism, fairness and justice, the five countries have staked out their positions on major regional and international issues and developed proposals to address them. They always advocate for the peaceful settlement of disputes through political and diplomatic means. 
It is obvious that the development of the BRICS agenda has closely followed changes in the international political and economic structure. After the 2008 economic crisis, the BRICS agenda focused on economic issues and paid attention to reversing the sluggish growth caused by the crisis. Since the 2011 Sanya summit, the scope of the BRICS agenda has gradually expanded from economic and political priorities to include humanitarian and social issues. In line with the development of the international community, various action plans have been carried out such as urban fora, health ministers meetings and cooperation in culture, sports, science and technology. Thus, the international political, economic and social structure is an external factor always affecting the BRICS agenda.

\section{Key Factor: The UN Charter}

BRICS exists within the UN framework and all BRICS summit declarations reaffirm support for the UN Charter. Prior to 2016, the BRICS agenda reiterated the importance of achieving the UN millennium development goals (MDGs) and highlighted the focus on preventing the potential impact of the economic and financial crisis on the achievement of MDGs in poor countries. The BRICS countries are called upon to make sustained efforts to achieve the MDGs by 2015, including providing technical cooperation and emergency support to poor countries to help them implement development policies and provide social security [BRICS, 2011]. Specifically, on the issue of poverty eradication, the international community is called upon to fully consider the special needs of developing countries, especially the least-developed countries, small island developing states (SIDS) and African countries when taking all necessary measures to eliminate poverty, enhance social inclusion and resolve inequality [BRIC, 2010]. This conforms to the MDG goal to end extreme poverty and hunger. When it comes to climate change, the five countries are obliged to adhere to the UN Framework Convention on Climate Change (UNFCCC) and the Kyoto Protocol and to promote their implementation to achieve a comprehensive, balanced and binding outcome. This is in line with the objective of environmental sustainability contained in the MDGs. The BRICS countries believe growth and development are essential for eradicating poverty and achieving the MDGs regarding sustainable economic development in developing countries [BRICS, 2011]. The climate change issue could be a key issue in which the BRICS countries, acting as a bloc, could take the lead in the discourse on sustainable development and climate change, the format of which will undergo inevitable changes in the coming decades [Ahsan, Gladun, 2016].

As "Transforming Our World: The 2030 Agenda for Sustainable Development" (Agenda 2030) came into effect on 1 January 2016, international development governance entered a new phase. The implementation of Agenda 2030 is the common task of current international cooperation and the common responsibility of the international community. The scope of the BRICS agenda expanded after 2016 to cover the objectives mentioned in Agenda 2030, and included more pragmatic cooperation projects for development. BRICS countries are supposed to work together to carry out Agenda 2030 to arrive at a consensus, increase the impetus for cooperation, win and create more opportunities for development and participate in and reform global governance. They have repeatedly affirmed their support for the UN Charter and commitment to the United Nations. As the universal intergovernmental organization, the United Nations is entrusted with the responsibility for maintaining international peace and security, advancing sustainable development and ensuring the promotion and protection of human rights and fundamental freedoms. The BRICS countries should adhere to the centrality of the universal collective security system enshrined in the UN Charter, work toward an international system based on international law with the UN Charter as its fundamental cornerstone and promote cooperation and stability in a multipolar order [BRICS, 2018]. 
BRICS endorses the internationally agreed development goals, including the UN Charter, MDGs and Agenda 2030. The negotiation and discussion of various issues such as economic development, political security, social development and people-to-people exchanges within BRICS takes the form of inclusive and transparent intergovernmental consultations under the UN mechanism, reflecting the universality and extent of the BRICS mechanism and the crucial impact of the UN Charter on the BRICS agenda.

\section{Another Factor: The Agenda of the G20 Summit}

The 2008 international financial crisis gave birth to the mechanisms of the G20 and BRICS summits. The former is the core mechanism of global economic governance and the "primary platform for international economic cooperation" in which advanced economies and emerging economies participate [G20, 2009]. The latter is a cooperation platform for emerging economies to strengthen policy coordination in global economic governance. As an international mechanism involving developed and emerging countries, the G20's main mode of operation is to discuss and seek consensus around specific issues, with the main topics focusing on economic governance and cooperation [Liu, 2015]. Since the elevation and transformation of the G20, emerging powers have gained opportunities to talk with developed countries within the structures of global economic governance. By participating in the dialogue, emerging powers can influence the G20 agenda. In turn, the G20 agenda has an important impact on the cooperation mechanisms of emerging powers.

From the perspective of cooperation goals, BRICS is a new platform for developing countries to carry out "South-South cooperation" within a multilateral framework in this new situation. It works as an effective supplement rather than alternative to "North-South cooperation" between developed and developing countries and aims to promote the democratization of international relations and enhance the effectiveness of global governance [Zhu, 2014]. In terms of cooperation channels, the BRICS countries emphasize the role of global governance mechanisms with broad representation and legitimacy such as the G20 and the United Nations. They support the G20 in its leading role in global economic governance in the post-crisis era and advocate the central role of the United Nations in addressing global challenges and threats. On the content of cooperation, the BRICS countries stress the need to actively promote the implementation of the agreements reached by the members at G20 summits and UN conferences, especially to assist developing countries in obtaining the means and conditions for implementing these agreements and policy commitments.

Judging from BRICS' macroeconomic policy coordination, the BRICS countries actively participated in the coordination of international macroeconomic policies to cope with the international financial crisis and promote global economic recovery, and formed an overall framework for promoting the "strong, sustainable, balanced growth" of the global economy within the structure of the G20 [BRICS, 2011]. The BRICS countries have promoted international financial supervision under the framework of the G20 and have achieved considerable development at the level of institutions and rules, breaking the irrational situation of developed countries' monopoly of international financial supervision and the myth of "financial market self-regulation." On trade issues, the BRICS countries have promoted the policy commitment to not adopt new protectionist trade measures in the short term through the G20 mechanism, thus safeguarding the authority of the World Trade Organization (WTO), the world's only multilateral trading system, in the long run. The 9th trade ministers meeting, which was held in Bali at the end of 2013, reached the first multilateral trade agreement in the 18 years since the establishment of the WTO, which has given the Doha development round and the WTO mechanism new development opportunities. 


\section{BRICS Summit Agenda Setting: A Historical Perspective}

\section{Cooperation Framework}

In the 10 BRICS summits held to date, the discussion of BRICS' cooperation mechanism has always been the priority of the BRICS declarations. Over the past decade, BRICS has established an effective cooperation framework taking the leaders summit as the core and covering various areas in a comprehensive and multilayered way. The annual leaders summit is the highest and most crucial level, providing political and strategic guidance on BRICS' cooperation. At the second level are high-level meetings of national security advisers, central bankers and ministers of foreign affairs, trade, industry, labour and employment, education, science and technology, agriculture, environment, health, disaster management, immigration and so on. These meetings have become an important way to implement decisions taken at leaders summits and the contribution of the high-level meetings of ministers to promoting cooperation is noted in each declaration by the leaders. For example, "We are satisfied with the outcome of the ministerial conferences on various areas and look forward to the meetings to be held in 2018" [BRICS, 2018]. In addition, it has become common practice for senior BRICS officials to meet at major multilateral diplomatic occasions such as the UN General Assembly and the G20. Such meetings have become a critical mechanism to promote pragmatic cooperation. At the third level are meetings of senior officials and working groups, providing technical support, such as the forum of state-owned enterprises, anti-corruption, science and technology, economy and trade, agriculture, hygiene, justice, antiterrorism, anti-drug and urbanization. Meanwhile, intellectual support can be obtained from the BRICS Business Council, the BRICS Think Tank Council, the BRICS Friendship City and Local Government Cooperation Forum, the BRICS Think Tank Forum, the BRICS Business Forum, the BRICS Financial Forum, the BRICS Meeting Forum and other cooperation mechanisms. At the fourth level are people-topeople exchanges including the BRICS Young Scientist Forum, the BRICS Small and Medium Enterprises Roundtable Conference, the BRICS Tourism Conference, the BRICS Friendship City Forum, the BRICS Film Festival, the BRICS Football Game for teenagers under the age of 17. All of these reflect the importance of culture as one of the driving forces of the fourth industrial revolution and the economic opportunities hiding behind it. The aim is to deepen the exchange of people in BRICS countries and create a favourable environment for long-term cooperation.

These four tiers of the BRICS cooperation mechanism, each with different significance, represent four main categories of the BRICS agenda. They are unified within the BRICS cooperation framework and serve as an important basis for the analysis of the BRICS agenda.

\section{The Scope of the BRICS Agenda}

The scope of cooperation among BRICS states has expanded in the past 10 years. BRICS has established a cooperative pattern driven by three factors including the economy, political security and people-to-people exchanges. Year by year, the text of the joint declaration of previous BRICS summits is enriched and the scope of the agenda expands.

The top priority of BRICS is economic and financial cooperation, and it is here that there have been the most prominent achievements. BRICS members have taken positions on the main dimensions of economic reform, including: changing the global system of reserve currencies, international financial institutions reform, replenishment of resources of multilateral development banks, creation of new financial safety nets, establishment of the BRICS development bank, creating effective surveillance systems, taking account of the systemic importance 
of participating economies, and overcoming financial imbalances [Larionova et al., 2012]. A great many achievements have been made. First, BRICS countries continue to deepen their economic cooperation, and BRICS' trade volume has increased from $\$ 93$ billion in 2006 to nearly $\$ 300$ billion in 2016 [National Bureau of Statistics of China, 2017]. Second, the establishment of the NDB and the CRA marked the beginning of a new stage for BRICS' countries financial cooperation. Third, the promotion of the reform of international financial institutions has increased the representation of emerging market and developing countries. Moreover, the BRICS agenda provides effective suggestions on global issues such as combating money laundering, anti-corruption cooperation, climate issues, food security and energy issues, and promoting the active participation of BRICS in global governance.

The BRICS agenda is concerned with issues of political security. With regard to major international and regional issues, including the situation in Iraq and Afghanistan, the Syrian crisis, the Iranian nuclear issue, the Ukrainian crisis, the Yemen conflict and the denuclearization of the Korean peninsula, BRICS countries stand in the position of emerging market and developing countries to call on the concerned parties to abide by the UN Charter, international law and the basic principles of international relations and to seek the settlement of disputes through political and diplomatic means. BRICS countries have carried out cooperation in combating terrorism and contributed to the conclusion of the Comprehensive Convention on International Terrorism at the UN General Assembly. The emergence of BRICS has generated a renewed debate about peacebuilding and donor activity. On the one hand, BRICS engages with the liberal peace paradigm and its often-neoliberal agenda that allows BRICS countries to protect sovereignty and the principle of non-intervention, pursue trade interests and advance their own interests. On the other hand, BRICS' involvement has challenged the Euro-Atlantic character of peacebuilding and development through the unfolding of its own donor and peace agendas [Richmond, Tellidis, 2013]. Additionally, BRICS countries have reached agreements on important issues such as exploring and utilizing outer space as well as fighting against piracy and cybercrime, strengthened practical cooperation and information exchange in generating renewable energy, utilizing nuclear energy for peace, climate change and food security. BRICS intends to explore the importance of treating food security and biotechnology as interdependent in the context of the performance of BRICS countries at the international level. This suggests that there are good reasons to believe that the relation between biotechnology and food security will become one of the major issues in BRICS' agricultural agenda. This is due to demographic trends and to high levels of poverty in the BRICS countries, to their existing dependency on GMOs (genetically modified organisms) provided by private companies and to the complementarities of their economies in the agricultural market [Mielniczuk, 2013].

BRICS' mission is the development of mutually enriching and beneficial cooperation among its members and the formation of a positive agenda on a wide range of issues. In 2015, BRICS countries further expanded and deepened their cooperation [Larionova, 2016]. Cooperation in people-to-people exchanges is flourishing, and the communication channels and personnel exchanges are continuously broadened in terms of customs, small- and mediumsized enterprises, gender equality, youth, education, culture, public health, friendship cities, tourism and sports. In conclusion, regarding cooperation BRICS has gradually shifted from a "dialogue forum" focusing on economic governance and general principles to an "all-round coordination mechanism" stressing the combination of economic and political governance as well as general principles and practice. BRICS is closer to the goal of a greater trade market, financial circulation, infrastructure connectivity and people-to-people exchanges which it put forward at the Durban summit [Zhu, 2014]. 


\section{A Possible Agenda for BRICS Summits in the Future}

\section{Core Topics Shared by BRICS Countries}

Based on the economic circumstances of the BRICS countries, economic issues will continue to dominate the agenda in the future. BRICS will keep calling on major developed economies and emerging market economies to maintain policy dialogue and coordination in the G20, the Financial Stability Board and other mechanisms in response to potential risks. The issues related to the global economic recovery, the reform of global economic and financial governance institutions and partnership in the fourth industrial revolution will be top priorities (Table 1).

Table 1. A Summary of the Concrete Action Plans and Results of the BRICS Agenda on Economic and Financial Cooperation

\begin{tabular}{|l|l|}
\hline \multicolumn{1}{|c|}{ Economic Issues } & \multicolumn{1}{|c|}{ Specific Measures in the Future } \\
\hline Macroeconomic Cooperation & Implement BRICS' Economic Partnership Strategy \\
\hline Trade Cooperation & $\begin{array}{l}\text { Fulfil BRICS' economic and trade cooperation guideline and advocate multilateral } \\
\text { trade }\end{array}$ \\
\hline Financial Cooperation & $\begin{array}{l}\text { Promote the development of BRICS development banks and contingency reserve } \\
\text { arrangements }\end{array}$ \\
\hline $\begin{array}{l}\text { Reforms of International Financial } \\
\text { Institutions }\end{array}$ & $\begin{array}{l}\text { Increase the share of emerging countries in international financial institutions and } \\
\text { propose that the personnel system of international financial institutions should } \\
\text { open to developing countries }\end{array}$ \\
\hline Network Cooperation & $\begin{array}{l}\text { Push forward The Memorandum of Understanding on Joint Research on } \\
\text { Distributed Accounting Technology and Block Chain Technology in the Context } \\
\text { of Digital Economic Development }\end{array}$ \\
\hline Aviation Cooperation & Accelerate the memorandum of understanding on BRICS' regional air partnership \\
\hline Customs Cooperation & $\begin{array}{l}\text { Drive early entry into force of the Agreement on Mutual Administrative Assistance } \\
\text { Between BRICS and Customs and Facilitating The Implementation of BRICS } \\
\text { Customs Action Plan }\end{array}$ \\
\hline Anti-Corruption Cooperation & $\begin{array}{l}\text { In accordance with their individual legal systems, carry out anti-corruption law } \\
\text { enforcement, loot-hunting and other criminal and non-criminal cooperation } \\
\text { involving anti-corruption, and appeal to the international community to refuse } \\
\text { to provide a haven for corrupt personnel and their assets }\end{array}$ \\
\hline
\end{tabular}

Source: compiled by the authors.

In the future BRICS will continue to strengthen multilateralism, promote global governance reform and address common challenges. With the support of the purposes and principles of the UN Charter, BRICS should assume the responsibility of maintaining international peace and security, promoting sustainable development and protecting human rights and fundamental freedoms. On climate cooperation, BRICS countries will continue to work constructively with the parties to the Paris Agreement; in energy cooperation, BRICS will focus on the support of the global sustainable development agenda, and will continue to work to achieve universal access to energy, energy security, energy affordability, pollution reduction and environmental protection.

In addition, regarding people-to-people exchanges and cooperation, BRICS countries will attach more importance to the promotion of cooperation in education, science and technology, youth, women's development and health governance. BRICS' involvement in the movement supporting Universal Health Coverage (UHC) is documented and reflected in political sup- 
port for most global commitments for UHC. Documented support for UHC and its focus on domestic challenges shows that individual BRICS countries are increasingly influential players in global health [Tediosi et al., 2016].

Table 2. A Summary of the Concrete Action Plans and Results of the BRICS Agenda of People-to-People Exchanges

\begin{tabular}{|c|c|}
\hline Issue & Specific Action Plans and Outcomes \\
\hline $\begin{array}{l}\text { Hygiene } \\
\text { Governance }\end{array}$ & $\begin{array}{l}\text { Hold a meeting of ministers of health and the High-Level Meeting on Traditional } \\
\text { Medicine; } \\
\text { Strengthen cooperation among BRICS states in the research and development of } \\
\text { vaccines; } \\
\text { Prepare to establish a BRICS vaccine research centre }\end{array}$ \\
\hline $\begin{array}{l}\text { Population } \\
\text { Question }\end{array}$ & $\begin{array}{l}\text { Propose the Cooperation on Population Matters 2015-2020 agenda; } \\
\text { Hold a meeting of ministers of immigration }\end{array}$ \\
\hline $\begin{array}{l}\text { Employment } \\
\text { Question }\end{array}$ & $\begin{array}{l}\text { Hold a meeting of ministers of labour and employment; } \\
\text { Promote the establishment of a network of labour research and training institutions }\end{array}$ \\
\hline $\begin{array}{l}\text { City } \\
\text { Question }\end{array}$ & $\begin{array}{l}\text { Hold the BRICS Friendship City and Local Government Cooperation Forum; } \\
\text { Hold meetings of local BRICS institutions }\end{array}$ \\
\hline $\begin{array}{l}\text { Education } \\
\text { Cooperation }\end{array}$ & $\begin{array}{l}\text { Establish a university alliance; } \\
\text { Conduct online university education; } \\
\text { Promote educational think tank cooperation; } \\
\text { Organize youth summer camps; } \\
\text { Set up think tank councils and academic fora }\end{array}$ \\
\hline $\begin{array}{l}\text { Youth } \\
\text { Communication }\end{array}$ & $\begin{array}{l}\text { Hold BRICS Youth Summit; } \\
\text { Hold BRICS Young Diplomats Forum; } \\
\text { Hold BRICS Young Scientist Forum }\end{array}$ \\
\hline $\begin{array}{l}\text { Technology } \\
\text { Communication }\end{array}$ & $\begin{array}{l}\text { Hold a meeting of ministers of science and technology; } \\
\text { Establish an agricultural technology exchange platform; } \\
\text { Hold a meeting of ministers of communications and the BRICS Young Scientist Forum }\end{array}$ \\
\hline $\begin{array}{l}\text { Tourism } \\
\text { Cooperation }\end{array}$ & Hold tourism conference \\
\hline $\begin{array}{l}\text { Culture } \\
\text { Communication }\end{array}$ & $\begin{array}{l}\text { Hold film festival; } \\
\text { Implement the action plan (2017-21) for the BRICS Intergovernmental Cultural } \\
\text { Cooperation Agreement }\end{array}$ \\
\hline $\begin{array}{l}\text { Sports } \\
\text { Communication }\end{array}$ & $\begin{array}{l}\text { Hold the BRICS Football Games for teenagers under the age of } 17 \text { and the BRICS } \\
\text { Games; } \\
\text { Set up the BRICS Sports Council }\end{array}$ \\
\hline
\end{tabular}

Source: BRICS summit declarations and actions plans [BRICS, 2011; 2012; 2013; 2014; 2015a; 2015b; 2016a; 2016b; 2017; 2018].

\section{Institution-Led Topics for the BRICS Agenda}

The number of countries involved with BRICS is increasing and the need to establish an access mechanism for new members cannot be ruled out. At the Sanya summit, South Africa became a new member, expanding the group and enhancing its representativeness. After the Sanya summit, BRICS summits gradually adopted a "BRICS + N" form of leadership dialogue according to which summit leaders and hosting leaders of developing countries must hold a dialogue. During the 2013 meeting in Durban, South Africa, BRICS countries held a dialogue with African leaders to discuss issues such as strengthening cooperation between BRICS countries and Africa. The sixth meeting in Brazil in 2014 provided an opportunity to promote 
cooperation between BRICS and South American countries. During the meeting in Russia in 2015, the BRICS countries held a meeting with the heads of state and government from the Eurasian Economic Union, the Shanghai Cooperation Organisation and observer countries, which laid a solid foundation for a broader and mutually beneficial dialogue. At the Goa summit in 2016, BRICS leaders held a dialogue with the leaders of the states of the Bay of Bengal Initiative for Multi-Sectoral Technological and Economic Cooperation (BIMSTEC), including Bangladesh, Bhutan, India, Myanmar, Nepal, Sri Lanka and Thailand, to explore the expansion of economic and trade relations between BRICS and BIMSTEC. The 2017 Xiamen summit in China replaced the "BRICS + N" model with a "BRICS +" model, reflecting the fact that dialogue is no longer confined to the developing countries in the region hosting the summit and now includes representatives of developing countries worldwide, greatly expanding BRICS' "circle of friends." This shows that BRICS countries, even while they are emerging powers, are still developing countries. Like other developing countries, BRICS countries aspire to reshape the international order in the new century. They are also rising forces in global structures and have accelerated development. BRICS has steadily strengthened its cooperation with developing countries over the past decade, and the development of the "BRICS +" model is expected to be the initial plan for increasing the membership of BRICS.

Under the guidance of the sustainable development goals (SDGs), BRICS should adjust and improve its existing cooperation mechanisms and closely integrate the BRICS process with the effective implementation of Agenda 2030. This agenda reflects the latest international consensus on development. It is a powerful tool to address global challenges and thus it is of great significance to global governance. The successful realization of Agenda 2030 cannot be separated from the cooperation of BRICS countries as the implementation of the agenda is very important to them. It is not only conducive to fostering new momentum for BRICS, but also provides a favourable opportunity for BRICS countries to actively participate in and reform global governance. At the same time, it is also an important means for China to build a community based on the shared future of humanity.

Many sustainable development goals have been incorporated into the BRICS agenda, including measures to strengthen scientific and technological cooperation, develop the digital economy, build energy bricks and develop a low-carbon economy, and strengthen infrastructure based on sustainable development. The focus should remain on key areas of cooperation to push forward the transformation and development of BRICS according to complementarity and common challenges.

The future agenda of BRICS will continue to develop under the G20 framework and may include the digital economy as a key item. In 2016, at China's G20 summit, the group identified the digital economy as an important topic of the summit, promoted the establishment of a digital economy working group and ultimately adopted the G20 Digital Economic Development and Cooperation Initiative. The digital economy was also one of the priorities of the 2017 G20 in Germany, with the first meeting of digital ministers being held in Dusseldorf. The issue of digital economy in Germany was focused on four core issues. First, how to promote global digitalization, including the development of innovative practices. Second, how to formulate international standards and how to speed up the network infrastructure. Third, how to build a secure network environment, and how to enhance the trust of countries in the development of the digital economy. Fourth, how to improve the mechanism of digital economic dialogue and consultation, including effective dialogue and cooperation between government and industry, supporting digital inclusive financial innovation, strictly guarding against risks and strengthening financial supervision. In addition, digital trade was also the focus of 2018 G20 Working Group on Trade and Investment which committed to promoting the establishment of international rules and regulations for digital trade, and the creation of relevant international institu- 
tional databases and indicator systems. In future agendas, BRICS countries should strengthen exchanges and cooperation in the field of digital economy to jointly meet the challenges of the digital divide, network and information security, and law and regulation. They should jointly promote the innovation and development of the digital economy to enhance the overall competitiveness of BRICS.

\section{New Initiatives and Alternatives From the BRICS States}

\section{China}

China's active participation and promotion of BRICS is China's international responsibility as an emerging power, an inevitable requirement of China's domestic economic development, and is based on the positive recognition of global governance and the inherent needs of China's diplomacy. China will continue to promote its establishment in the future. Focusing on the BRICS partnership, China will actively promote the development of "BRICS +" model.

In the past 10 years, China has adhered to the spirit of BRICS which values open, inclusive, cooperative and win-win partnerships, and has unswervingly promoted sustainable economic growth and comprehensive economic cooperation. China will continue to shape a favourable external environment for development, enhance the moral appeal, actively participate in cooperation among BRICS countries and contribute Chinese wisdom to BRICS. China proposed "BRICS +" at the Xiamen summit, which is conducive to creating an open and diverse network of development partners, allowing more emerging market and developing countries to participate in solidarity to achieve mutual benefits. The Xiamen declaration focused on the "BRICS +" cooperative governance approach and emphasized the continued expansion of extensive economic and political cooperation beyond the five BRICS states. In addition, China will continue to support trade liberalization and oppose protectionism. In November 2018, China held the first China International Import Expo in Shanghai. This was a major initiative for China to open its market to the world and set up a new platform for all countries to enter the Chinese market. In the future, China will continue to adhere to the basic principles of "pragmatic negotiation, openness, tolerance, mutual benefit and win-win." China will advocate strengthening the solidarity of BRICS to deepen its strategic partnership, grasp the opportunities of the new industrial revolution, enrich pragmatic cooperation, hold high the banner of multilateralism, improve the global governance system, strengthen the cooperation mechanism and promote smooth and far-reaching cooperation in BRICS.

\section{Russia}

Russia will continue to make BRICS one of the priorities of its diplomatic strategy, will and strive to promote it as an important coordination mechanism for international politics and economics. In the future, with the exception of the trade finance sector, Russia will also focus on technology and education cooperation among the BRICS countries.

Russia regards BRICS as its current platform for multilateral diplomacy and as a bridge for promoting cooperation with developing countries. The healthy development of BRICS is conducive to Russia's position in the international political system. It will help Russia maintain its global strategic balance and increase its global influence. In 2015-16 the Russian Federation held the rotating presidency of BRICS, and one of Russia's goals was to gradually transform BRICS from a dialogue forum into a comprehensive strategy and interaction mechanism for "hot" political and economic issues. In summits since then, Russia has gradually strengthened its position in the BRICS, contributed to the promotion and consolidation of its reputation in- 
ternationally, and helped reform the international monetary system by supporting the establishment of BRICS' own financial mechanism. The BRICS presidency presented an excellent opportunity for Russia to appreciate the support of its partners in times of considerable difficulties, and also to demonstrate itself as a reliable partner and responsible global actor [Panova, 2015]. Within the framework of BRICS, the establishment of a national-level payment system and rating mechanism is also a useful practice. At the same time, Russia has always been committed to promoting dialogue and aligning different parties' positions on strategic stability, pursuing international and regional security, preventing the proliferation of weapons of mass destruction, resolving regional conflicts, and maintaining regional stability. It also emphasizes that all parties should continue their efforts to strengthen the central role of the United Nations in ensuring global security and stability and to preserve and consolidate the role of the UN Security Council. In addition, Russia will continue to focus on technology and education cooperation among BRICS countries. At the 2015 Ufa summit, Russia proposed the launch of the BRICS Network University, an inter-university cooperation and student exchange programme, and in November 2015 the third BRICS Education Ministers Meeting was held in Moscow. The representatives of the ministries of education in the five countries signed the memorandum of understanding on the Establishment of the BRICS Network University. In July 2017, the Beijing Education Declaration was signed by the ministers of education who proposed the continuation of support for the BRICS Network University through cooperation in education, research and innovation. Russia believes that in the context of the fourth industrial revolution, cooperation in education, science and technology will be the driving force for BRICS' economic growth. With the efforts of the five countries, education in the BRICS countries will advance.

\section{Brazil}

BRICS is the product of Brazil's great power diplomacy and South-South cooperation. In the future, Brazil will focus on green economy cooperation and bioenergy utilization in order to support Brazil's sustainable economic development as well as contribute to the development of BRICS and the globe.

Although Brazil is currently facing great political uncertainty, BRICS has greatly benefited Brazil. Therefore, the Brazilian government will continue to participate in BRICS, especially to promote pragmatic cooperation within the group. In the past 10 years, Brazil has played an important role in BRICS, actively promoting financial reform, opposing trade protectionism, pursuing trade liberalization, seeking solutions to climate change, pursuing social development, and supporting counterterrorism peacekeeping. The 2014 Brazil Fortaleza summit declaration called for the post-2015 development agenda to be based on and fully respect the Rio principles of sustainable development, highlighting Brazil's influence on this topic. Brazil is concerned about the development of the green economy. The Brazilian economy faces structural problems and thus is focusing on building a new international environmental development order, while strengthening environmental dialogue, green investment opportunities centred on infrastructure, and green financial innovation centred on the NDB. On issues such as climate change and energy cooperation, Brazil has repeatedly proposed effective cooperation programmes. Especially in the use of bioenergy, Brazil implemented the Ethanol Plan in the 1970s, using sugar cane to make alcohol for use in automobiles in order to replace fossil fuels with renewable energy and to promote environmental protection. In addition, Brazil has rich experience in environmental protection legislation, environmental governance institutions and environmental protection technology innovation. In 2019, Brazil will assume the presidency of BRICS and host the 11th summit of BRICS leaders. What changes will happen to the country's cooperation with BRICS? We will wait and see. 


\section{India}

In the future, India will continue to keep BRICS at the core of its diplomacy, focusing on promoting economic and financial cooperation among BRICS countries and participating in global governance and rule-making through BRICS to ensure India's geographical influence in South Asia and Southeast Asia.

BRICS provides an opportunity for India to participate in global economic governance. With the continuous strengthening of its economy, India's diplomacy has shown positive trends in recent years and has shown strong interest in multilateral cooperation. From the perspective of India's participation in BRICS in the past decade, India will likely focus on enhancing complementarity and cooperation between BRICS countries, especially in the economic and financial fields, as well as addressing infrastructure, the inefficiency of global governance and the promotion of cooperation between BRICS and India's leading regions. India actively promotes BRICS and its leading regional connectivity programme - the Bengal Initiative for MultiSectoral Technical and Economic Cooperation (BIMSTEC) - focusing on "three key areas" (the Himalayas, the Bay of Bengal and the Mekong subregion) and "two fulcrum countries" Myanmar as the fulcrum of the land connection with the Association of Southeast Asian Nations (ASEAN) countries and the Greater Mekong region, and Sri Lanka as the fulcrum of the Bay of Bengal and the Indian Ocean maritime transport and safe passage. In this context, Sri Lanka supports the organizational framework of the Bangladesh Bay Initiative to explore the potential of economic and trade cooperation with neighbouring countries and ensure its own geographical influence on South Asia and Southeast Asia. In order to highlight India's appeal and willingness to invest in BIMSTEC and to promote economic and trade cooperation between BRICS and BIMSTEC, India used its opportunity as host of the 2016 BRICS summit to convene a meeting of leaders of BIMSTEC and BRICS states. By actively participating in BRICS cooperation, India can further enhance its international influence, accumulate political resources and lay a solid foundation to become a global political power.

\section{South Africa}

In the future, South Africa will further support BRICS's efforts to play a greater role in Africa's development and will promote the further development of the "BRICS +" model. South Africa will focus on topics such as the promotion of employment, energy cooperation, marine economy and tourism cooperation among BRICS countries.

Since becoming a member of BRICS, South Africa has further developed relations with other BRICS countries. Against the backdrop of the rise of protectionism in Europe and the United States and the decline of South Africa's domestic economy, South Africa hopes to deepen its cooperation with other BRICS countries, achieve domestic economic transformation, promote industrialization and regional integration, expand employment, enhance energy cooperation, promote energy diversification, increase marine economic cooperation and promote tourism and visa facilitation. Over 10 years, the strategic cooperation between BRICS countries has continued to deepen, economic and trade cooperation has been strengthened and people-to-people exchanges have become more frequent. The ever-evolving BRICS mechanism has established a higher-level platform to help South Africa and other African countries to achieve social and economic development, and has promoted the transformation of global governance mechanisms. South Africa regards Africa's stability and prosperity as the foundation of national security and development and thus actively encourages more African countries to establish partnerships with BRICS. The establishment of the Africa Regional Centre of the NDB opened the services of the bank to the African continent. It will not only provide construction 
funds for African countries, but also provide consulting and training services to help governments improve public financial management capabilities. The construction of the African Regional Centre and the financing of sustainable development projects are two major ways that African countries can achieve development with the assistance of BRICS. The history of South Africa's participation in BRICS shows that the differences between BRICS countries and their respective challenges are precisely the charm of BRICS and the reason for its existence. From the "Bandung spirit" to the "BRICS spirit," developing countries are committed to seeking common ground while preserving differences, helping each other to achieve win-win results and jointly exploring the development path. It is believed that in the next decade, BRICS will help the African continent to usher in "golden development."

\section{Conclusion}

It is widely acknowledged that although BRICS has encountered some problems and difficulties in the past 10 years, its potential and advantages in terms of resources, market and labour have not changed, and the long-term development prospects are still promising. BRICS should conform to the historical trend, seize development opportunities, work to overcome challenges and play a constructive role in building a new type of international relations and global community.

Based on a review of BRICS summit agendas, it can be concluded that the development status of BRICS countries as emerging powers is a fundamental factor affecting the development of the BRICS agenda; the current international political situation and the status of international economic development are important external factors, and the UN Charter and the development of the G20 summit agenda are key factors affecting BRICS' agenda. The development of the BRICS agenda is characterized by the maturity of the cooperation mechanism and its expanding scope. In predicting the agenda for future presidencies, we firmly believe that BRICS will prioritize economic issues while seeking to both strengthen multilateralism in political cooperation and promote global governance reform. In addition, BRICS must recognize that culture is the driving force of the fourth industrial revolution and contains important economic opportunities. BRICS should continue to broaden the field of people-to-people exchanges and give full play to the importance of cultural cooperation. In the future, BRICS may focus on adding new members, closely integrating the BRICS cooperation process with the effective implementation of Agenda 2030, while including the digital economy on the development agenda. Looking back at the history of BRICS, various countries have demonstrated sincere cooperation and formed a series of cooperation mechanisms. The active participation of these countries in global cooperation has provided effective experience for developing countries and has made important contributions to strengthening North-South cooperation. Looking forward to the next decade, BRICS should focus on promoting cooperation among developing countries, give full play to the potential of developing countries, try to narrow the gap with developed countries, actively participate in global governance, strengthen the breadth and depth of pragmatic cooperation and promote sustainable development of cooperation among BRICS states.

\section{References}

Ahsan D., Gladun E. (2016) BRICS Countries' Political and Legal Participation in the Global Climate Change Agenda. Social Science Electronic Publishing, vol. 3, no 3, pp. 8-42.

BRIC (2009) Joint Statement of the BRIC Countries' Leaders. Yekaterinburg, 16 June. Available at: http:// brics.utoronto.ca/docs/090616-leaders.html (accessed 29 May 2019). 
BRIC (2010) Summit of Heads of State and Government: Joint Statement. Brasilia, 15 April. Available at: http://brics.utoronto.ca/docs/100415-leaders.html (accessed 29 May 2019).

BRICS (2011) Sanya Declaration. Sanya, 14 April. Available at: http://brics.utoronto.ca/docs/110414-leaders. html (accessed 29 May 2019).

BRICS (2012) Delhi Declaration and Action Plan. New Delhi, 29 March. Available at: http://brics.utoronto. ca/docs/120329-delhi-declaration.html\#actionplan (accessed 29 May 2019).

BRICS (2013) BRICS and Africa: Partnership for Development, Integration and Industrialisation. Available at: http://brics.utoronto.ca/docs/130327-statement.html (accessed 29 May 2019).

BRICS (2014) Fortaleza Declaration and Action Plan. Fortaleza, 15 July. Available at: http://brics.utoronto. ca/docs/140715-leaders.html (accessed 29 May 2019).

BRICS (2015) Ufa Declaration. Ufa, 9 July. Available at: http://brics.utoronto.ca/docs/150709-ufadeclaration_en.html (accessed 29 May 2019).

BRICS (2015) Ufa Action Plan. Ufa, 9 July. Available at: http://brics.utoronto.ca/docs/150709-ufa-actionplan-en.html (accessed 29 May 2019).

BRICS (2016) Goa Declaration. Goa, 16 October. Available at: http://brics.utoronto.ca/docs/161016-goa. html (accessed 29 May 2019).

BRICS (2016) Goa Action Plan. Goa, 16 October. Available at: http://brics.utoronto.ca/docs/161016-goaaction-plan.html (accessed 29 May 2019).

BRICS (2017) Xiamen Declaration. Xiamen, 4 September. Available at: http://brics.utoronto.ca/docs/170904xiamen.html (accessed 29 May 2019).

BRICS (2018) Johannesburg Declaration. Johannesburg, 26 July. Available at: http://brics.utoronto.ca/ docs/180726-johannesburg.html (accessed 29 May 2019).

G20 (2009) G20 Leaders Statement: The Pittsburgh Summit. Pittsburgh, 24-25 September. Available at: http://www.g20.utoronto.ca/2009/2009communique0925.html (accessed 29 May 2019).

Budhwar P., Tung R. L., Varma A., Do, H. (2017) Developments in Human Resource Management in MNCs From BRICS Nations: A Review and Future Research Agenda. Journal of International Management, vol. 23, no 2, pp. 111-23.

Guo S., Shi M. (2015) The Possibility of Building a New Type of International Relations System: Viewing the Reform of the World Order From the Establishment of the New Development Bank and Contingent Reserve Arrangement. International Review, no 2 (in Chinese).

G20 (2009) G20 Leaders Statement: The Pittsburgh Summit. Pittsburgh, 24-25 September. Available at: http://www.g20.utoronto.ca/2009/2009communique0925.html (accessed 29 May 2019).

Horwitz F., Budhwar P. (eds) (2015) Handbook of Human Resource Management in Emerging Markets. Cheltenham: Edward Elgar.

Larionova M., Rakhmangulov M., Shelepov A., Sakharov A., Medyshevsky N. (2012) BRICS Cooperation: A Resource for Forging BRICS and G20 Decisions in the Key Areas of International Financial and Economic Architecture. International Organisations Research Journal, vol. 7, no 4, pp. 199-238.

Larionova M. (2016) Russian BRICS Presidency: Models of Engagement With International Institutions. International Organisations Research Journal, vol. 11, no 2, pp. 82-101.

Li D., Xu X. (2015) BRICs Cooperation Mechanism under the Perspective of Global Governance. Reform, no 10, p. 10. Available at: http://kns.cnki.net/KCMS/detail/detail.aspx?dbcode=CJFQ\&dbname=CJFDLAST2 015\&filename $=$ REFO201510007\&uid $=$ WEEvREcwSIJHSldRa1FhdkJkVG1BK3krZlA1bGc1ZnU3bzYyNFl aMktOND0 $=\$ 9 A 4 h F$ YAuvQ5obgVAqNKPCYcEjKensW4IQMovwHtwkF4VYPoHbKxJw!!\&v=MTc1MTJ GeXJtVjc3Tk55ak5ZYkc0SDIUTnI0OUZZNFI4ZVgxTHV4WVM3RGgxVDNxVHJXTTFGckNVUkxPZlll $\mathrm{ZHM}=$ (accessed 29 May 2019) (in Chinese).

Li W. (2013) The BRICS Mechanism and International Financial Governance Reform. International Review, no 1, p. 36. Available at: http://kns.cnki.net/KCMS/detail/detail.aspx?dbcode=CJFQ\&dbname=CJFD2013 \&filename $=$ GJGC201301006\&uid $=$ WEEvREcwSIJHSldRa1FhdkJkVG1BK3krZlA1bGc1ZnU3bzYyNFlaM ktOND0=\$9A4hF_YAuvQ5obgVAqNKPCYcEjKensW4IQMovwHtwkF4VYPoHbKxJw!!\&v=MDY4NjlEaD 
FUM3FUcldNMUZyQ1VSTE9mWWVkc0Z5cm1WN3JPSWlmTWJiRzRIOUxNcm85RllvUjhlWDFMdXh ZUzc= (accessed 29 May 2019) (in Chinese).

Liu H. (2015) The Broadening of the G20 Agenda and Its Impact on Regime Effectiveness. International Forum, no 3, p. 7. Available at: http://kns.cnki.net/KCMS/detail/detail.aspx?dbcode $=$ CJFQ\&dbname $=$ CJF DLAST2015\&filename $=$ GJLT201503002\&uid=WEEvREcwS1JHSldRa1FhdkJkVG1BK3krZ1A1bGc1ZnU3 bzYyNFlaMktOND0=\$9A4hF_YAuvQ5obgVAqNKPCYcEjKensW4IQMovwHtwkF4VYPoHbKxJw!!\&v=M jgyMjlEaDFUM3FUcldNMUZyQ1VSTE9mWWVkc0Z5cm1WTHpQSWlmSGVyRzRIOVRNckk5RlpvUjh lWDFMdXhZUzc= (accessed 29 May 2019) (in Chinese).

Mielniczuk F. (2013) Food Security, Biotechnology, and the BRICS: A Necessary Relationship. International Affairs Forum, vol. 4, no 1, pp. 65-9.

National Bureau of Statistics of China (2017) BRICS Joint Statistical Publication. Available at: http://www. stats.gov.cn/ztjc/ztsj/jzgjlhtjsc/jz2017/201709/t20170901_1530127.html (accessed 29 May 2019) (in Chinese).

O’Neill J. (2001) Building Global Economics BRICs. Global Economics Paper No 65, Goldman Sachs \& Co. Available at: https://www.goldmansachs.com/insights/archive/archive-pdfs/build-better-brics.pdf (accessed 29 May 2019).

Panova V. (2015) BRICS Security Agenda and Prospects for the BRICS Ufa Summit. International Organisations Research Journal, vol. 10, no 2, pp. 90-104.

Richmond O., Tellidis I. (2013) The BRICS and International Peacebuilding and Statebuilding. Norwegian Centre for Conflict Resolution. Available at: https://noref.no/Publications/Themes/Peacebuilding-andmediation/The-BRICS-and-international-peacebuilding-and-statebuilding (accessed 29 May 2019).

Tediosi F., Finch A., Procacci C., Marten R., Missoni, E. (2016) BRICS Countries and the Global Movement for Universal Health Coverage. Health Policy Plan, vol. 31, no 6, pp. 717-28.

Wilson D., Purushothaman R. (2003) Dreaming With BRICs: The Path to 2050. Global Economics Paper No 99, Goldman Sachs \& Co. Available at: https://www.goldmansachs.com/insights/archive/archive-pdfs/ brics-dream.pdf (accessed 29 May 2019).

Zhu F. (2010) The Construction of Cooperation Mechanisms in Emerging Powers: A New Momentum to Promote the Development of International Institutions. Contemporary World, no 11, p. 7. Available at: http:// kns.cnki.net/KCMS/detail/detail.aspx?dbcode=CJFQ\&dbname=CJFD2010\&filename $=$ JSDD201011007\&u id=WEEvREcwSIJHSldRa1FhdkJkVG1BK3krZlA1bGc1ZnU3bzYyNFlaMktOND0=\$9A4hF_YAuvQ5obg VAqNKPCYcEjKensW4IQMovwHtwkF4VYPoHbKxJw!!\&v=MjM3Mjg3RGgxVDNxVHJXTTFGckNVUk xPZ11lZHNGeXJsVjd6QUx6N1Bhckc0SD1ITnJvOUZZNFI4ZVgxTHV4WVM= (accessed June 13 2019) (in Chinese).

Zhu J. (2014) Transformation of the BRICS Cooperation Mechanism. International Review, no 3, pp. 72-3. Available at: http://kns.cnki.net/KCMS/detail/detail.aspx?dbcode=CJFQ\&dbname=CJFD2014\&filenam $\mathrm{e}=$ GJGC201403007\&uid=WEEvREcwS1JHSldRa1FhdkJkVG1BK3krZlA1bGc1ZnU3bzYyNFlaMktOND $0=\$ 9 A 4 h F \_Y A u v Q 5 o b g V A q N K P C Y c E j K e n s W 4 I Q M o v w H t w k F 4 V Y P o H b K x J w ! ! \& v=M T Q x N D I I Z H N G e$ XJsVkw3TklpZk1iYkc0SDIYTXJJOUZZNFI4ZVgxTHV4WVM3RGgxVDNxVHJXTTFGckNVUkxPZlk= (accessed June 13 2019) (in Chinese). 


\title{
Изменение и развитие повестки будущих председательств БРИКС'
}

\author{
Ш. Гуо, Х. Чжан, В. Ши
}

Гуо Шуюн - профессор, декан Школы международных и публичных отношений Шанхайского университета международных исследований; China, Shanghai 200083, 550 Dalian Road (W); E-mail: syguo@shisu. edu.cn

Чжан Ханьвэнь - соискатель PhD в Школе международных и публичных отношений Шанхайского университета международных исследований; China, Shanghai 200083, 550 Dalian Road (W); E-mail: 0174100989@ shisu.edu.cn

Ши Вэйпин - соискатель $\mathrm{PhD}$ в Школе международных и публичных отношений Шанхайского университета международных исследований, Ассоциированный профессор Шанхайского университета традиционной китайской медицины; China, Shanghai 200083, 550 Dalian Road (W); E-mail: susanswp@126.com

В 2009 г. в Екатеринбурге состоялся первый саммит лидеров БРИКС. С тех пор термин «БРИКС» постепенно эволюционировал, превратившись из научной концепции в реальный механизм сотрудничества, который играет все возрастаюшую роль на мировой политической арене. За прошедшие десять лет обсуждаемая в рамках саммитов БРИКС повестка последовательно обогащалась, а принимавшиеся лидерами БРИКС совместные плань действий отличали прагматизм и эффективность. Данная статья посвящена, во-первых, изучению повестки десяти прошедших саммитов БРИКС и оценке факторов, влияющих на ее формирование. Во-вторых, в статье прослеживаются развитие повестки БРИКС и произошедшие в ней за десять лет изменения. В-третьих, анализируются тренды, которые могут определить будушую повестку объединения, а также имеющиеся ожидания и планы развития механизма сотрудничества БРИКС. Цели настоящей статьи: проследить развитие и изменение повестки саммитов БРИКС за прошедшие десять лет; обобщить основные факторы, влияющие на изменение повестки БРИКС; на основе анализа выявленных факторов спрогнозировать возможное развитие повестки БРИКС в будущем, а также изучить комплексные проблемы и вызовы, с которыми сталкиваются страны БРИКС в сложившейся международной обстановке, сформулировать аргументированные предложения по их преодолению через сотрудничество и рекомендации по продвижению будущего сотрудничества.

Ключевые слова: БРИКС; повестка саммита; глобальное управление; развивающиеся державы

Для цитирования: Гуо Ш., Чжан Х., Ши В. (2019) Изменение и развитие повестки будущих председательств БРИКС // Вестник международных организаций. Т. 14. № 2. С. 109-127 (на русском и английском языках). DOI: $10.17323 / 1996-7845-2019-02-05$.

\section{Источники}

Ahsan D., Gladun E. (2016) BRICS Countries' Political and Legal Participation in the Global Climate Change Agenda // Social Science Electronic Publishing. Vol. 3. No. 3. P. 8-42.

BRIC (2009) Joint Statement of the BRIC Countries' Leaders. Yekaterinburg, 16 June. Режим доступа: http://brics.utoronto.ca/docs/090616-leaders.html (дата обращения: 29.05.2019).

BRIC (2010) Summit of Heads of State and Government: Joint Statement. Brasilia, 15 April. Режим доступа: http://brics.utoronto.ca/docs/100415-leaders.html (дата обращения: 29.05.2019).

${ }^{1}$ Статья поступила в редакцию в октябре 2018 г.

Статья получила поддержку со стороны очной программы Шанхайского университета международных исследований «Цивилизационный диалог по вопросам социального конструирования: выводы из дискурса международной политической социологии». 
BRICS (2011) Sanya Declaration. Sanya, 14 April. Режим доступа: http://brics.utoronto.ca/docs/110414leaders.html (дата обрашения: 29.05.2019).

BRICS (2012) Delhi Declaration and Action Plan. New Delhi, 29 March. Режим доступа: http://brics.utoronto.ca/docs/120329-delhi-declaration.html\#actionplan (дата обращения: 29.05.2019).

BRICS (2013) BRICS and Africa: Partnership for Development, Integration and Industrialisation Режим доступа: http://brics.utoronto.ca/docs/130327-statement.html (дата обращения: 29.05.2019).

BRICS (2014) Fortaleza Declaration and Action Plan. Fortaleza, 15 July. Режим доступа: http://brics.utoronto.ca/docs/140715-leaders.html (дата обращения: 29.05.2019).

BRICS (2015) Ufa Declaration. Ufa, 9 July. Режим доступа: http://brics.utoronto.ca/docs/150709-ufa-declaration_en.html (дата обращения: 29.05.2019).

BRICS (2015) Ufa Action Plan. Ufa, 9 July. Режим доступа: http://brics.utoronto.ca/docs/150709-ufa-action-plan-en.html (дата обращения: 29.05.2019).

BRICS (2016) Goa Declaration. Goa, 16 October. Режим доступа: http://brics.utoronto.ca/docs/161016goa.html (дата обращения: 29.05.2019).

BRICS (2016) Goa Action Plan. Goa, 16 October. Режим доступа: http://brics.utoronto.ca/docs/161016goa-action-plan.html (дата обращения: 29.05.2019).

BRICS (2017) Xiamen Declaration. Xiamen, 4 September. Режим доступа: http://brics.utoronto.ca/ docs/170904-xiamen.html (дата обращения: 29.05.2019).

BRICS (2018) Johannesburg Declaration. Johannesburg, 26 July. Режим доступа: http://brics.utoronto.ca/ docs/180726-johannesburg.html (дата обращения: 29.05.2019).

G20 (2009) G20 Leaders Statement: The Pittsburgh Summit. Pittsburgh, 24-25 September. Режим доступа: http://www.g20.utoronto.ca/2009/2009communique0925.html (дата обращения: 29.05.2019).

Budhwar P., Tung R. L., Varma A., Do, H. (2017) Developments in Human Resource Management in MNCs From BRICS Nations: A Review and Future Research Agenda // Journal of International Management. Vol. 23. No. 2. P. 111-23.

Guo S., Shi M. (2015) The Possibility of Building a New Type of International Relations System: Viewing the Reform of the World Order From the Establishment of the New Development Bank and Contingent Reserve Arrangement // International Review. No. 2. (In Chinese)

G20 (2009) G20 Leaders Statement: The Pittsburgh Summit. Pittsburgh, 24-25 September. Режим доступа: http://www.g20.utoronto.ca/2009/2009communique0925.html (дата обращения: 29.05.2019).

Horwitz F., Budhwar P. (eds) (2015) Handbook of Human Resource Management in Emerging Markets. Cheltenham: Edward Elgar.

Larionova M., Rakhmangulov M., Shelepov A., Sakharov A., Medyshevsky N. (2012) BRICS Cooperation: A Resource for Forging BRICS and G20 Decisions in the Key Areas of International Financial and Economic Architecture // International Organisations Research Journal. Vol. 7. No. 4. P. 199-238.

Larionova M. (2016) Russian BRICS Presidency: Models of Engagement with International Institutions // International Organisations Research Journal. Vol. 11. No. 2. P. 82-101.

Li D., Xu X. (2015) BRICs Cooperation Mechanism under the Perspective of Global Governance Reform // International Review. No. 10. Р. 10. Режим доступа: http://kns.cnki.net/KCMS/detail/detail.aspx?dbcode= CJFQ\&dbname $=$ CJFDLAST2015\& filename $=$ REFO201510007\&uid $=$ WEEvREcwSIJHSldRa1FhdkJkVG1B K3krZlA1bGc1ZnU3bzYyNFlaMktOND0=\$9A4hF_YAuvQ5obgVAqNKPCYcEjKensW4IQMovwHtwkF4VYPoHbKxJw!!\&v=MTc1MTJGeXJtVjc3Tk55ak5ZȲkc0SDIUTnI0OUZZNFI4ZVgxTHV4WVM3RGgxVD NxVHJXTTFGckNVUkxPZ11lZHM= (дата обращения: 29.05.2019). (In Chinese)

Li W. (2013) The BRICS Mechanism and International Financial Governance Reform // International Review. No. 1. Р. 36. Режим доступа: http://kns.cnki.net/KCMS/detail/detail.aspx?dbcode=CJFQ\&dbname $=$ CJFD2013\&filename $=$ GJGC201301006\&uid $=$ WEEvREcwSIJHSldRa1FhdkJkVG1BK3krZlA1bGc1ZnU 3bzYyNFlaMktOND0=\$9A4hF_YAuvQ5obgVAqNKPCYcEjKensW4IQMovwHtwkF4VYPoHbKxJw!!\&v=MDY4NjlEaDFUM3FUcldNMUZyQ1VSTE9mWWVkc0Z5cm1WN3JPSWImTWJiRzRIOUxNcm85R1lvUjhlWDFMdXhZUzc= (дата обращения: 29.05.2019). (In Chinese) 
Liu H. (2015) The Broadening of the G20 Agenda and Its Impact on Regime Effectiveness // International Forum. No. 3. P. 7 Режим доступа: http://kns.cnki.net/KCMS/detail/detail.aspx?dbcode=CJFQ\&dbname $=$ CJFDLAST2015\&filename $=$ GJLT201503002\&uid $=$ WEEvREcwSIJHSldRa1FhdkJkVG1BK3krZlA1bGc 1 ZnU3bzYyNFlaMktOND0=\$9A4hF_YAuvQ5obgVAqNKPCYcEjKensW4IQMovwHtwkF4VYPoHbKxJw!!\&v=MjgyMjlEaDFUM3FUcldNMÜZyQ1VSTE9mWWVkc0Z5cm1WTHpQSWlmSGVyRzRIOVRNckk5 RlpvUjhlWDFMdXhZUzc= (дата обращения: 29.05.2019). (In Chinese)

Mielniczuk F. (2013) Food Security, Biotechnology, and the BRICS: A Necessary Relationship // International Affairs Forum. Vol. 4. No. 1. P. 65-9.

National Bureau of Statistics of China (2017) BRICS Joint Statistical Publication. Режим доступа: http:// www.stats.gov.cn/ztjc/ztsj/jzgjlhtjsc/jz2017/201709/t20170901_1530127.html (дата обращения: 29.05.2019). (In Chinese)

O’Neill J. (2001) Building Global Economics BRICs. Global Economics Paper No 65, Goldman Sachs \& Co. Режим доступа: https://www.goldmansachs.com/insights/archive/archive-pdfs/build-better-brics.pdf (дата обращения: 29.05.2019).

Panova V. (2015) BRICS Security Agenda and Prospects for the BRICS Ufa Summit // International Organisations Research Journal. Vol. 10. No. 2. P. 90-104.

Richmond O., Tellidis I. (2013) The BRICS and International Peacebuilding and Statebuilding. Norwegian Centre for Conflict Resolution. Режим доступа: https://noref.no/Publications/Themes/Peacebuilding-andmediation/The-BRICS-and-international-peacebuilding-and-statebuilding (дата обращения: 29.05.2019)

Tediosi F., Finch A., Procacci C., Marten R., Missoni, E. (2016) BRICS Countries and the Global Movement for Universal Health Coverage // Health Policy Plan. Vol. 31. No. 6. P. 717-28.

Wilson D., Purushothaman R. (2003) Dreaming With BRICs: The Path to 2050. Global Economics Paper No 99, Goldman Sachs \& Со.. Режим доступа: https://www.goldmansachs.com/insights/archive/archivepdfs/brics-dream.pdf (дата обращения: 29.05.2019).

Zhu F. (2010) The Construction of Cooperation Mechanisms in Emerging Powers: A New Momentum to Promote the Development of International Institutions // Contemporary World. No. 11. Р. 7. Режим доступа: http://kns.cnki.net/KCMS/detail/detail.aspx?dbcode $=$ CJFQ\&dbname $=$ CJFD2010\&filename=JSDD201011 007\&uid=WEEvREcwSIJHSldRa1FhdkJkVG1BK3krZlA1bGc1ZnU3bzYyNFlaMktOND0=\$9A4hF_YAuvQ5obgVAqNKPCYcEjKensW4IQMovwHtwkF4VYPoHbKxJw!!\&v=MjM3Mjg3RGgxVDNxVHJXTTFGc kNVUkxPZ111ZHNGeXJsVjd6QUx6N1Bhckc0SDIITnJvOUZZNFI4ZVgxTHV4WVM= (дата обращения: 13.06.2018) (In Chinese).

Zhu J. (2014) Transformation of the BRICS Cooperation Mechanism // International Review. No. 3. P. 72-3. Режим доступа: http://kns.cnki.net/KCMS/detail/detail.aspx?dbcode=CJFQ\&dbname $=$ CJFD2014\&filen ame $=$ GJGC201403007\&uid $=$ WEEvREcwSIJHSldRa1FhdkJkVG1BK3krZlA1bGc1ZnU3bzYyNFlaMktON D0=\$9A4hF_YAuvQ5obgVAqNKPCYcEjKensW4IQMovwHtwkF4VYPoHbKxJw!!\&v=MTQxNDllZHNG eXJsVkw3TklpZk1iYkc0SDIYTXJJOUZZNFI4ZVgxTHV4WVM3RGgxVDNxVHJXTTFGckNVUkxPZlk= (дата обращения: 13.06.2018). (In Chinese) 